\title{
IMF Lending and Poverty in Developing Countries
}

\author{
Eleftherios Makedonas ${ }^{1}$ \\ Sotirios Bellos ${ }^{2}$ \\ Subasat Turan ${ }^{3}$ \\ DOI 10.1515/jheec-2015-0015
}

\begin{abstract}
An arduous debate has developed around the question of whether the multiple IMF's 'stabilization' interventions in developing countries have actually met one of the most important of its initial programmatic goals, i.e., the provision of resources to members, with a view to eliminating temporary Balance of Payments maladjustments, avoiding at the same time destroying 'national or international prosperity'. More importantly, there have been many voices claiming that these programs have rather accentuated poverty than alleviated it. We explore this claim both theoretically and empirically. Our results show an unequivocal negative relationship between IMF lending and poverty in the developing world.
\end{abstract}

Keywords: IMF, Monetarism, poverty, Human Development Index, Infant Mortality Rate. JEL Classification: E51, E630, 0190.

1 University of Macedonia, e-mail: lefmak@gmail.com

2 University of Macedonia, e-mail: sotiriosbellos@gmail.com

3 Izmir University of Economics, e-mail: turan.subasat@izmirekonomi.edu.tr 


\section{Introduction}

The International Monetary Fund (IMF) was established in 1944 as a mechanism for ensuring exchange rate stability. According to its Article of Agreement, IMF's initial objectives were to facilitate the expansion and balanced growth of international trade, to promote exchange rate stability among its members, and to make its resources temporarily available to them, under adequate safeguards, so that they correct existing maladjustments in their balance of payments. Thus, by definition, its role was defined as a short-term stabilization one (Dabour, 1999). Hence, the initial distinction between IMF's Stabilization Programs (SPs) as opposed to the respective World Bank's (WB) Structural Adjustment Programs (SAPs), which are characterized by a more long-term character.

With the collapse of the Bretton Woods system of pegged exchange rates, within a context of uncontrollably inflating prices at an international scale, with the old ghosts of hyperinflation dangerously revived, and many countries in desperate need for credit capital in order to finance their bloating BoP deficits created by the oil crisis, IMF was faced with a never known before demand for its financial resources (Diz, 1984).

As the 1982 debt crisis exploded, IMF's activity expanded to developing countries as well (Polak, 1991; Collier and Gunning, 1999). Regarding the specific IMF policies adopted in the new era, they heavily drew from the monetarist theoretical framework, with its emphasis on 'current account and balance of payments improvements and inflation rate reduction' (Pastor, 1987). It was believed-contrary to the Keynesian paradigm - that both the BOP problems and inflation were due to an excessive domestic demand which, in any event, must be abruptly compressed. On the monetary side of the economy, demand contraction can be achieved via a respective money supply contraction. A simple currency devaluation will not work but only temporarily (Whitman, 1975). More drastic means of suppressing the supposedly excessive demand are needed. Under this perspective, alongside the currency devaluation measure, contractionary fiscal and monetary policies have also been implemented including drastic wage freezes, price and interest rate increases, limits on domestic bank credit, additional taxation, etc. (Girvan, 1980; Foxley, 1983; Díaz-Alejandro, 1984).

Rapidly, IMF's 'stabilization' policies-which should normally be limited to the 'shortterm' BoP and inflation problems-intermingled with some more 'structural adjustment' ones, aiming at adjusting the prevalent domestic conditions of the recipient economy to the 'free market' paradigm. Trade and price liberalization reforms, reforms affecting the taxation system and government spending, financial and banking system deregulation, labor market reforms, extensive privatizations, etc. were also incorporated to the IMF agenda(Williamson, 1990; Polak, 1990, 1997; Mosley, Subasat \& Weeks (1995); Mussa \& Savastano, 2000).

Ample critique has ever since been directed towards both the efficiency of such policies and the theoretical premises nurturing them, especially from the 1980 s on. It has been claimed that there is no relationship whatsoever between an expansionary fiscal or monetary policy and persistent inflation, as the example of the U.S.A. of the year 1982 
(Dell, 1982), and those of Brazil and Mexico of the early 1980s (Díaz-Alejandro, 1984) attest.

The call of the U.S. government itself, at the twilight of the Bretton Woods era, that 'equivalent incentives for adjustment' be 'evenhandedly' applied 'to all nations' (Annual Report of the Council of Economic Advisers, 1973) ${ }^{4}$ seems to have made the necessary connection between the specific IMF policies implemented and the claim for an equitable distribution of the adjustment burdens among different nations and among different social strata within a single nation, accurately prefiguring the passionate controversy around the effect of the IMF conditionalities on poverty that was soon to follow.

Many voices ever since have insisted that, instead of promoting prosperity, IMF's policies have had disastrous effects on the recipient economies' overall economic activity, with devastating repercussions on poverty.

This paper sheds light on these repercussions of the IMF's conditionalities on poverty (the Infant Mortality Rate-IMR included), and the overall human wellbeing, as measured by the Human Development Index (HDI). Our focus is on developing countries.

Our empirical results show that poverty is invariably aggravated, while the overall human quality of life is also seriously afflicted by the IMF policies.

The paper is structured as follows: Section 2 traces the theoretical foundations of the IMF conditionalities. Section 3 recapitulates the basic theoretical arguments concerning the effects on poverty of these conditionalities. Section 4 outlines the respective empirical findings of this literature, with an eye to our own results. Section 5 explains the data, variables, and methodology used. Section 6 discusses our findings, and Section 7 concludes the paper.

\section{The theoretical foundations of the IMF stabilization programs (SPs)}

Much of the ideology nurturing the specific policies prescribed by the IMF during the last three decades can be explained by reviewing some of the basic premises of the economic theory known as Monetarism. The disbelief that traditional monetary policy, as bequeathed by the Keynesian school of thought can in reality provide full employment and growth, alongside the conviction that price stability must be the fundamental longrun economic objective can be deemed as the linchpin of the Monetarist theory (Friedman, 1982).

A predilection for some mechanical rules with regard to the quantity of money supplied to the economy and an aversion for discretionary interventions of the monetary authorities are instead the basic ideas prevailing in the Monetarist school, at least since Henry Simons (1936) urgently called for not missing “... the essential point, namely, that

\footnotetext{
4 The same idea is also included in the IMF's own Article of Agreement. Dell (1982) notes that according to the Article I (v), '...the correction of maladjustments in the balance of payments should be undertaken 'without resorting to measures destructive of national or international prosperity".
} 
definite, stable, legislative rules of the game as to money are of paramount importance to the survival of a system based on freedom of enterprise".

Seeking to establish such a set of a few simple mechanical monetary rules, sufficient in themselves for a harmoniously functioning economy, Monetarism predicated that:

1. "Money alone matters in determining "money things"' (Kaldor, 1970), or at least, "only money matters much" in the words of Heller (Friedman and Heller, 1969), whereas other things, such as fiscal policy or taxation do not (really) matter.

2. The Keynesian premise that under conditions of high unemployment-where the 'liquidity preference' is almost absolute-monetary policy as expressed by lowering the interest rates will not be of much help, and that instead, fiscal policy interventions by the central authorities are the ones needed, has proved to be erroneous, as the post-war experience of high inflation has shown in many developed western countries (Friedman, 1969).

3. What this experience tells us is that the 'easy-money' fiscal policies followed during the first post-war decades, achieved via significant government spending increases and tax cuts can only lead to a disproportionate creation of new money, a 'hidden tax', which is in fact inflation (Friedman, 1969; Friedman, 1975).

4. This is the reason why fiscal policy interventions are in any case detrimental for the economy, and monetary policy must be the prevalent one, where the term 'monetary policy' stands for "the effect of the actions of the monetary authorities on the stock of money-on the number of pieces of paper in people's pockets, or the quantity of deposits on the books of banks" (Friedman, 1969).

5. Coming back to the idea of Simons and Friedman for a few simple but stable monetary rules, the publicly announced adoption of a fixed annual rate of money growth-e.g., 3\% or 4\%- would suffice for a stable GNP growth and overall economic performance (Friedman, 1969; Friedman, 1983).

A more recent development in the Monetarist theory-the so-called 'monetary approach to the balance of payments' - has associated ideas like the aforementioned to the issue of the specific IMF 'conditionalities'.

The basic idea behind the 'monetary approach to the balance of payments' has been that, in the face of a BoP deficit, the demand side of the economy must somehow be compressed. Alexander (1952) would say that the 'absorption of goods and services' by the economy 'relative to its income' must be reduced, i.e., total consumption-private and governmental-must shrink. Meade $(1956$; 1957) would have stressed the necessity for a simultaneous mix of disinflationary policies domestically-or else, a generalized deflation of 'total domestic monetary expenditure'-and exchange rate devaluations, i.e., rendering the relative prices of the exports and imports of tradables higher compared to those of the non-tradables.

In any event, in matters of BoP problems, Monetarism has predicated both the devaluation and the internal deflation strategies-what Harry G. Johnson (1972) termed "expenditure-reducing" and "expenditure-switching" policies, respectively.

Brought to its extremes, the Monetarist approach to the BoP turns to what Whitman et al. (1975) has termed 'global Monetarism'.

A 'global Monetarist' BoP model accommodates the following three basic assumptions 
(Dornbusch, 1973; Whitman et al., 1975; Wanniski, 1975):

1. The 'neutrality assumption', according to which the level of real income is exogenously determined, and there exists a one-to-one relationship between the demand for money and the aggregate price level, i.e., money is 'neutral' vis-à-vis real variables. In its most extreme implications, it means that fiscal policy is completely irrelevant.

2. The assumption of 'perfect commodity arbitrage', according to which, the 'law of one price' holds in an integrated global economy.

3. The so-called 'monetary approach' to the BoP holds, which means that: a) the national demand for money of a country consists of a domestic credit and an international reserves component (Laffer \& Agmon, 1978), and that a BoP surplus or deficit is equivalent to the rate of change of the reserves' stock held by the country; b) the desired level of expenditure is the difference between the income and the 'hoarding' of the economy, where 'hoarding' is defined as the difference between the 'desired' and the 'actual' stock of money, or else, the demand and supply of money.

According to a 'global Monetarist' model (Dornbusch, 1973; Whitman et al., 1975; Wanniski, 1975), devaluation raises the domestic price level of the economy, bringing about a subsequent increase in the demand for money. If the economy's 'hoarding' is defined as the difference between its demand for money and its supply of money, devaluation will increase 'hoarding', and since the latter is viewed as definitionally equal to the BoP deficit (or surplus), the economy's BoP will improve.

With the emergence of some even more radical views within the context of 'global Monetarism'-e.g., the so-called 'Mundell-Laffer hypothesis' (Wanniski, 1975)devaluation was finally seen as having no real positive effects for an economy with BoP problems. It was even thought of as resulting in more inflation. Hence, the "expenditureswitching" policies-according to Harry G. Johnson's term-were seen as the only feasible alternative.

Heavily borrowing from such theoretical premises, the IMF has formulated its own monetary model for the BoP-also termed the 'Polak model', after the name of the main theorist who has developed it. According to Polak (1990), the model aimed at explaining in a simple and practical manner, 'the effects on both income formation and the balance of payments of the two most important exogenous variables' which affected most of the postwar economies, namely, the 'autonomous changes in exports and the creation of domestic bank credit; or, in monetary terms, foreign and domestic autonomous additions to a country's money supply'. Changes in a country's money supply are defined as a function of the changes in its income; they are also definitional equal to the sum of the changes in its foreign reserves stock and changes in its domestic credit provided by its banking system; changes in the country's foreign reserves stock are on their part expressed as exports minus imports, plus net capital inflows of the nonbank sector; finally, demand for imports is defined as a function of the country's income.

Along time, the initial IMF monetary model has been further enriched, giving more 
emphasis on the domestic credit variable ${ }^{5}$. Additional policy variables were incorporated, which formerly belonged to the WB's 'structural adjustment' agenda. It also accommodated insights borrowed from the Monetarist theory, regarding the exchange rate depreciation, and the growth issues. However, the main ideas stemming from the Monetarist theoretical current as presented above have been preserved: contracting income domestically via austere fiscal discipline strategies, encouraging private sector initiative and financing while drastically shrinking the public sector (privatizations and massive firings included), limiting domestic credit expansion, depreciating domestic currency when possible, etc. (Polak, 1989).

The IMF's monetary model and its policy implications as reflected in its conditionalities have ever since been subject to fierce criticism. Krugman \& Taylor (1978), and DíazAlejandro (1963), for example, have stressed the fact that devaluation has a strong contractionary effect, leading to falling output and employment, alongside a redistributive effect toward 'economic actors with high marginal propensities to save'. Kaldor (1982, quoted in Dell, 1982) has even made the point that 'A large-scale devaluation may well be followed by a price upheaval that ends up by reproducing, at a much higher level of prices, the same price and cost relationships as had prevailed before the devaluation'.

Others have underlined the fact that austere fiscal discipline and the suppression of the demand side of the economy as predicated by Monetarism leads to the same results as devaluation, i.e., severe contractions in production and employment (Petras and Brill, 1986; Palley, 2009; Boyer, 2012;Perotti, 2012;Wade and Sigurgeirsdottir, 2012).

Many voices have gone even further, claiming that the real beneficiaries of the austerity programs are few in number-mainly the strongest players-e.g., firms and social classes connected with export production, foreign investors and transnational firms, large agricultural interests, and state managers (Bernal, 1984; Cline 1983, quoted in Walton \& Ragin, 1990; Foxley 1981, quoted in Walton \& Ragin, 1990; Pastor, 1987).

This ultimate point relates the theoretical background of the IMF conditionalities and their possible effects on the main issues of this paper-poverty and wellbeing in Third World countries where IMF programs have been implemented. The next section reviews more in depth the relevant literature.

\section{The IMF-poverty controversy in literature}

An extensive literature has been developed around the question whether the IMFimposed policies, also known as 'conditionalities' have actually helped the recipient countries to overcome their economic difficulties and achieve a higher level of wellbeing for their peoples, or if, on the contrary, they have further immersed them in a vicious circle of continuous economic stagnation and impoverishment.

Regarding poverty, there exist those who consider IMF's policies as generally benevolent

5 Which was split in two parts-private and public-the former to be encouraged, and the latter usually discouraged (Polak, 1989). 
for the amelioration of poverty. A typical argument offered contends that by rendering both tradable and non-tradable goods more expensive, devaluation favours the expansion of production in both sectors. To the extent that the ones who are traditionally involved in the production and exporting of tradables in Third-World countries are the poor farmers, poverty can be significantly ameliorated via the devaluation measure by boosting their income, according to this argument (Johnson and Salop, 1980; Díaz-Alejandro, 1984; Kanbur, 1987; Kyle, 1989; Hajro and Joyce, 2009). According to a related argument, trade liberalisation might alleviate the poor, mostly via indirect ways, e.g., through the overall increase in growth rates achieved (Bevan et al. 1990, quoted in Collier and Gunning 1999; Berg and Krueger, 2002; Dollar and Kraay, 2004), when all of the restrictions imposed on free trade which in the last analysis castigate the tradables sector-e.g., import tariffs, cascaded tariff structures, excessive export taxes, etc.-be eliminated (Elbadawi, 1993). It is similar to the aforementioned devaluation argument, in the sense that the ones involved in the tradables sector of an average Third World country are poor small farmers or simple agricultural workers.

Others stress the fact that there exists a relationship between expansionary monetary and fiscal policies, the creation of budget deficits, inflation, and as a result, current account imbalances and a bloating foreign debt (Wiesner, 1985; Rodrik, 1996; Bird, 2004). Others have argued more explicitly about the effectiveness of some contractionary fiscal policies as a means for preventing such undesirable phenomena, which can even lead to pro-poor results if properly implemented (Adam and Bevan, 2001; Ames, Brown, Devarajan and Izquierdo, 2001).

However, even authors with a 'pro-IMF' stance like Collier and Gunning (1999: 637) have admitted that '[...] some subgroups of the poor are avoidably hurt by adjustment programs' mainly because of the abrupt and indiscriminate manner they were introduced (Weissman, 1990; De Vogli and Birbeck, 2005). Many other authors share the same point of view on the grounds that:

- The already weak purchasing power of the poor is further curbed by the currency devaluation measure (Meller, 1991; Meertens, 2000), which increases the price of imported goods and causes inflation (Konadu and Agyemang, 2000).

- Austere fiscal policies have in most cases targeted the health and education sectors $^{6}$, which are of an utmost importance for the poor ones (Weissman, 1990; Lugalla, 1995; Chossudovsky, 2003).

- Extensive privatization schemes, agreed upon between impotent and corrupted local governments, and powerful multinationals with a blatantly higher negotiating power, are claimed to have led to an unprecedented raise of unemployment (Weissman, 1990; Adedeji, 1999; Banchiringah, 2006), large-scale forceful population displacements (Hilson and Potter, 2005) and denial of access to basic goods like water and electricity for vast parts of the domestic populations (Ismi, 2004; Saprin, 2001). It is also debatable whether the privatized services' overall

\footnotetext{
${ }^{6}$ Ismi (2004: 13) mentions that 'Ten African governments spent more on debt repayments than on primary education and health care combined in 2002'. And, in Bradshaw et al. (1993: 634), we read: 'The Third World currently is transferring a net total of $\$ 20$ billion a year to the developed world, with debt repayments and interest charges far exceeding new loans and aid from abroad'.
} 
performance has at all been improved, or instead severely deteriorated (Bayliss, 2002).

Regarding infant mortality, it should in no case be deemed as a merely demographic indicator since it embraces even more of the 'causal influences on the quality of life and the survival chances of people' (Sen, 1995: 11) than the ones captured by some of the traditionally used purely economic variables. This is why many authors regard it as an additional poverty indicator (Shen and Williamson, 2001; Loko et al., 2003). As to the relevant literature, it is also characterized by two diametrically opposed strands.

In the 'pro-IMF' strand, Hojman(1996) suggests that small doses of political will of the local governments is all that is needed so that the existing-not additional-economic resources are redirected towards the reduction of the high infant mortality rates in the poor Third World countries.

More abundant seems to be the anti-IMF strand. Bradshaw, Noonan, Gash and Buchmann Sershen (1993) and Shen and Williamson (2001) confirm the negative impact IMF lending has on infant mortality, which is effectuated via indirect channels, e.g., economic growth slowdown, deficient immunization and health care, overurbanization, low school enrolment rates, etc. Others, like Frey and Field (2000) argue that the detrimental effects of foreign debt on infant mortality are direct and more pronounced even if political democracy proves to be an agent able per se to counteract such detrimental effects (Shandra et al., 2003).

As to the impact of IMF lending on the HDI, there exist those who insist that a positive effect of external debt-predominantly IMF-funded-on the HDI can be observed (Lohani, 2005), even if it is mediated, indirectly, by the growth and trade liberalization reforms channels (Hajro and Joyce, 2009).

There also exist those who detect a significant deterioration in terms of human development wherever the IMF intervened (Dabour, 1999; Geo-Jaja and Magnum, 2001; Adeyemi, Ijaiya, Ijaiya, \& Kolawole 2006). Some of them, like Huang (1995), proceed even further, claiming that foreign debt has been converted in recent times in the principal form of dependency 'crippling economies and societies in the poor countries' (175). 


\section{The controversy put in numbers - is it resolved or further intensified?}

At the empirical level, and regarding the poverty literature, most of the authors belonging to the 'pro-IMF strand' use 'headcount' and 'gap' poverty variables, they adopt a country case-study strategy, and use mostly simple descriptive statistics for their empirical analysis.

In the 'pro-IMF' strand, Handa and King (1996) focus on Jamaica, and find that poverty was impressively reduced during 1989-1993, when most of the World Bank and IMF-led reforms took place. Dercon and Krishnan (1998) obtain the same finding for the case of Ethiopia in the 1989-1995 period. Crisp and Kelly (1999) divide their sample of 16 LA countries according to whether they have been good 'reformers' or not during the 1980's, and conclude that the 'hypothesis that ostensive structural adjustment is associated with the greatest increases in poverty' is not supported by their data. Oberdabernig (2012) uses a panel of 86 low and middle-income countries for the period 1982-2009, and finds that poverty has been lower for non-participant countries, but only during the first two years of program implementation.

In the scarce 'anti-IMF' poverty strand, brief time spans, descriptive statistics, and a casestudy strategy are the prevalent traits of the empirical analyses offered. Jamal (2003) focuses on the case of Pakistan, for the 1987-1988 and 1988-1999 periods, and claims that poverty was further intensified in the latter, both in 'headcount' and 'gap' terms ${ }^{7}$. Anwar (1996) also finds a further accentuation of poverty in Pakistan due to the IMF presence, during the 1987-1988 and 1990-1991 periods.

Among the 'pro-IMF' authors of the infant mortality literature, Hojman (1996) finds a negative impact of external debt on IMR-i.e., lower infant mortality rates-for a crosssection sample of 22 Central American and Caribbean countries in 1992. Noorbakhsh and Noorbakhsh (2006) find a statistically significant drop in infant mortality for all of the groups of recipient countries they examine independently of whether they are 'good' or 'bad' compliers.

In the opposite, 'anti-IMF' strand, Frey and Field (2000) find that excessive external debt-as depicted by their 'debt dependence' variable ${ }^{8}$ - directly leads to an increased IMR, for a cross section sample of 59 low and middle-income countries in year 1991. Bradshaw et al. (1993), and Shen and Williamson (2001) obtain the same negative impact on IMR, but they claim that this is done via more indirect manners: a negative impact of debt on growth and calories per capita in the first instance, and on growth and secondary school enrolment in the second. Interestingly enough, IMF economists Loko, Mlachila, Nallari and Kalonji (2003) find both a direct, as well as an indirect impact of external debt $^{9}$ on infant mortality via a deterioration of the growth rates.

The same radical opposition and inconclusiveness in the respective empirical findings are also the main characteristics of the HDI literature. Most of the authors regress HDI on broad sets of macroeconomic variables as well as variables related to the IMF-programs implementation (duration, completion, etc.). Hajro and Joyce (2009) find that the HDI is

\footnotetext{
71988 was the year of initiation of the first World Bank and IMF-led structural adjustment program in Pakistan.

${ }^{8}$ Defined as the ratio of bilateral and multilateral debt to GNP. So, Frey and Field (2000) do not isolate an IMF lending variable, but generally refer to the external debt factor.

${ }^{9}$ Loko et al. (2003) address the issue of the impact of external indebtedness on poverty in general, and not of IMF lending specifically.
} 
positively affected by the IMF programs, mainly through the increased degree of trade openness and growth rates achieved, for a panel of 82 developing countries during 19852000. Lohani (2005) finds that both foreign aid per capita and total external debt exert a positive and statistically significant impact on HDI. He considers this finding as 'counterintuitive', however (117). Noorbakhsh and Noorbakhsh (2006) introduce what they term 'temporal' and 'comparative temporal' analyses, and find that the HDI is positively influenced by a high degree of IMF compliance, only on a 'temporal' basis, i.e., that HDI has increased after the implementation of some IMF program.

The strategy of regressing HDI on broad sets of macroeconomic variables is also prevalent in what could be called an 'anti-IMF' strand in the HDI literature. Gudikunst (2004) obtains the 'perplexing' (37) finding of a small, negative, but statistically significant impact of IMF lending on HDI, for a sample of 17 Latin American countries during 1980-2000. Huang (1995) also finds a strong negative and statistically significant impact of his 'debt dependency'10 variable on HDI. Adeyemi et al. (2006) find a negative but statistically insignificant estimated value for external debt on HDI, for a cross section of 41 Sub-Saharan countries in year 2003.

\section{Empirical model, variables and data used}

What stems overall from the literature presented so far is a sharp contradiction in the arguments and empirical findings offered, whereas in many cases, the lack of formal econometric analyses is overarching. Where formal treatment is absent, theoretical argumentation-mainly based on radical ideological oppositions-flourishes. Many of the 'pro'/'anti'-IMF strands are quite scant in number of studies offered. Our empirical analysis aims at filling these gaps.

We introduce a panel data regression model of the form:

$(P O V / I M R / H U M D E V)_{i t}=c+a O I L_{i t}+b U R B A N_{i t}++c I M F_{i t}+e_{i t}$,

where $i$ refers to the country, $t$ at the time period, and ' $(P O V / I M R / H U M D E V)_{i t}$ ' is the set of poverty variables, the HDI and IMR included.

We have employed panel data analysis since it provides more degrees of freedom when compared to cross-sectional or time-series methods. Furthermore, it is also able to address possible omitted variables bias and heterogeneity issues. We have opted for the random effects panel data method, basically because it is more economical in terms of the numbers of parameters estimated (Gujarati, 2011).

Potential Heteroskedasticity problems were resolved by using the Newey-West Heteroskedasticity and Autocorrelation Consistent Standard Errors. All variables are in logarithmic form to remedy heteroskedasticity. We tested stationarity of the variables by adopting the Levin, Lee and Chu and the Philips Perron methods with a Newey West bandwidth selection, all of which confirmed the variables' stationarity.

\footnotetext{
${ }^{10}$ Huang (1995) uses several measures for debt dependency, 'aiming at differentiating the effects of various types of debts' on human development (172), such as: 1) multilateral debt as a percentage of GDP, 2) bilateral debt as a percentage of GDP, 3) private debt as a percentage of GDP, 4) multilateral and bilateral debt as a percentage of GDP. 
A brief explanation of the variables of equation 1 classified in dependent and independent follows. More information on the sources of the respective data is offered in Table 1 of Appendix 1. A broad time span (1985-2009) has been used. Nevertheless, the low density of the available observations for almost all of these variables calls for the necessary caution when interpreting the respective results. More detail regarding the data sources is presented in Table 1 of Appendix 1.The list of the developing countries included in the sample is presented in Table 2 of Appendix 1.

\section{Dependent variables}

Poverty variables: We have used two categories of poverty variables-'gap' and 'headcount'. According to the World Development Indicators (2013) of the World Bank, the former are defined as 'the mean shortfall from the poverty line (counting the non poor as having zero shortfall), expressed as a percentage of the poverty line'. The latter are defined as: 'Population below $\$ \mathrm{x} .00$ a day is the percentage of the population living on less than \$x.00 a day at 2005 international prices'. Thus the variable 'HC 1.25' (see Table 1 of Appendix 2) measures the percentage of the population living on $\$ 1.25$ per day.

Among the 'gap' and 'headcount' poverty variables, variables for the rural (GAP RUR LN and HC RUR LN), and the urban (GAP URB LN and HC URB LN) sector of the economy have also been included. They are structured in the same way as the other 'gap' and 'headcount' variables, with the only difference that they introduce the rural and urban poverty lines as their benchmark for poverty.

Finally, two other variables introducing the national poverty line as a poverty benchmark have been used (GAP NAT POV LN and HC NAT POV LN).

We have also used the Infant Mortality Rate ${ }^{11}$ (variable IMR) as an additional poverty variable, for the reasons already exposed in Section 2. According to the OECD Glossary of Statistical Terms, 'the infant mortality rate is the number of deaths under one year of age occurring among the live births in a given geographical area during a given year, per 1,000 live births occurring among the population of the given geographical area during the same year'.

'Human development' variables: As a measure for a population's overall well-being and human development we have used the HDI index (variable HDI).According to the Human Development Report (2011) it is a composite index that measures a country's average achievements in three basic aspects of human development: longevity, knowledge, and a decent standard of living. Longevity is measured by life expectancy at birth; knowledge by a combination of the adult literacy rate and the combined primary, secondary, and tertiary gross enrolment ratio; and the standard of living by Gross National Income (GNI) per capita, (UN 2011; Hajro and Joyce, 2009). HDI's spectrum of values oscillates between 0 and 1 . Countries with an index over 0.8 can be considered as belonging to the High Human Development group. Countries with values between 0.5 and 0.8 can be considered as belonging to the Medium Human Development group, whereas values below 0.5 classify a country into the Low Human Development group.

\section{Independent variables}

${ }^{11}$ Henceforth IMR 
We measure IMF lending with our variable IMF, which corresponds to the ratio of total IMF lending to the GDP of a recipient country, expressed in current dollars value. A negative and statistically significant coefficient for IMF in equation 1 would corroborate the arguments and empirical findings of what we have termed 'pro-IMF' strand in Sections 3 and 4, alluding to poverty alleviation as the amount of money provided by the IMF increase in a recipient country. On the contrary, a positive and statistically significant coefficient would mean a deleterious impact of IMF lending on poverty, coming in line with the respective arguments of the 'anti-IMF' strand as detected in Sections 3 and 4.

We have also used two additional independent variables-OIL and URBAN-to control for other factors which might be interacting in a statistically significant manner with our poverty and human development ones. These variables should not be correlated with IMF-the main regressor of the model-so that multicollinearity be avoided (Gujarati, 2011). They should however possess additional explanatory power for poverty and human development matters. OIL is used as a proxy for the existence of natural resources and is measured in thousands barrels per day. URBAN represents the percentage of urban to total population of a recipient country.

Regarding OIL, a generally inverse relationship between poverty and human development and the existence of abundant natural resources would sound the logical thing to occur in real life. However, the so-called 'Dutch disease' or 'resource curse' literature contests this claim. Labour and capital resources transfers from the more traditional sectors of an economy-manufacturing and services-towards a newlyemerged sector of natural resources exploitation may ultimately lead to a deindustrialization process rather than to increased development for the economy as a whole (Corden and Neary, 1982; Gylfason, 2001). Especially for the poor Third World countries, the so-called 'political resource curse' literature has claimed that affluence in natural resources might also condemn a poor country to authoritarianism at the political level, especially there where authoritarian predispositions abound-e.g., in most of the African countries (Morrison, 2007; Jensen and Wantchekon, 2004). This seems to be the case with countries like Nigeria. Akinbobola and Saibu (2004), for example, wonder how a country so rich in natural resources can be so irrevocably immersed in perennial poverty; or Ghana, where natural resources affluence has really proved to be something like a 'curse', leading to deleterious environmental alterations (Downing, 2000; Akabzaa and Darimani, 2001; Hilson and Potter, 2005), and poverty (Ismi, 2004; Banchirigah, 2006).

Regarding urbanization, it is widely accepted that it is going to be the principal mode of growth for the total human population in the years to come. For example, the UN (2012) expects that, by mid-century, the total urban population of Earth is going to be almost equal to the world's total population as of 2002. Most of the 'megacities' formed by then are going to be located in Third World countries, meaning that there is a marked mutation in the urbanization process from the developed towards the developing world. Ravallion (2001) has made the connection between an increased urban share of total population and the respective percentage of the urban poor people share, stating that the latter is an increasing convex function of the former. Indeed, Haddad, Ruel, and 
Garrett (1999) offer evidence that both the absolute number and the share of urban poor people are increasing for the majority of the 8 developing countries they examine. Several studies exist today, offering evidence and arguments for a 'hand-in-hand' process of urbanization, impoverishment and structural adjustment policies in the developing world (Walton and Ragin, 1990; and, Minujin, 1995 for the case of Latin America; Lugalla, 1995 for the case of Tanzania; Kanji, 1995 for the case of Zimbabwe, etc.). Failing to address the factor of urbanization in a study aiming at tracing possible causalities between poverty-related issues and IMF lending might render a serious omission.

\section{Empirical results - discussion}

Table 1 of the Appendix 2 summarizes the empirical results for poverty. Both of the two categories of variables used-'headcount' and 'gap'-are expected to obtain high values for developing countries, under the hypothesis that IMF lending has an aggravating impact on poverty. This hypothesis is fully supported from the results. Poverty is further accentuated by the IMF lending factor. IMF invariably obtains positive and statistically significant estimated coefficient values for all of the poverty variables.

The fact that the coefficient values for the headcount and gap variables tend to be slightly higher at the $\$ 1.25$ than the $\$ 2$ level (columns 2 and 1 of Table 1 for the 'headcount variables, and columns 4 and 3 for the 'gap' variables) tempts us to deduce a disproportionately negative effect of IMF lending for the poorest segments of the population, reminding us of the argument of a kind of 'multiplicative' effect the IMF-led policies exert especially on the poorest ones found in Grant (1984) or Jolly (1991).

The national poverty line variables - both on a 'headcount' and a 'gap' basis-confirm the fact that the IMF lending further deteriorates the existing levels of poverty at a national level (columns 5 and 6 of Table 1).

No different picture is sketched out from the respective results for our 'headcount' and 'gap' variables for the rural and urban sectors of the economy: all four variables, i.e., 'GAP RUR LN', 'HC RUR LN', 'GAP URB LN', and 'HC URB LN' (columns 7-10 of Table 1 of Appendix 2) obtain equally positive-even though still small in absolute termsvalues, with small corresponding p-values for the respective t-tests, confirming that the IMF lending also negatively affects poverty in a statistically significant manner, be it in the urban or the rural segments of the economy. Out of the four, the urban 'gap' variable produces the biggest estimated value (0.11), and the biggest t-test value, insinuating that the urban working class of the recipient countries might be the one hit harder under circumstances of abrupt adjustment, a result which seems to corroborate similar evidence and arguments met in Killick and Malik (1992), Lopes (1999), Chossudovsky (2003), Mazur (2004), and The Chronic Poverty Research Centre - CPRC (2004), among others. ${ }^{12}$ This finding, we deem, confirms our initial intuition that urbanization is infrangibly entwined with structural adjustment and poverty, and justifies the selection of URBAN as an additional controlvariable in equation 1.

12 Contrary to them, other authors have claimed that urban poverty has instead declined after the implementation of structural adjustment programs, e.g., Appleton (1999) for the case of Uganda or Thiele (2003) for the case of Bolivia. 
Another noteworthy trait of the results on poverty is that the 'gap' variables almost invariably produce the biggest estimated coefficient values for IMF as compared to the respective 'headcount' ones, the only exception being noticed at the 'GAP $\mathbf{1 . 2 5}$ /'HC $\mathbf{1 . 2 5}$ ' pair. This evidence alludes to a clear deterioration in terms of real disposable income on the event of an IMF intervention than in terms of the number of people affected. The distance from the various definitions of a 'poverty line' in real income terms broadens with IMF lending, and only in the case of the poorest segment of the population-the one earning $\$ 1.25$ daily at the most-does the number of people affected by poverty get more salient than the gap from the poverty limit expressed in income terms.

In an attempt to pay tribute to the kind of sensibility about the effects of structural adjustment programs on the children of the Third World, met in for example Grant (1984), Helleiner, Cornia and Jolly (1991), and Jolly (1991), we have also used the IMR as a dependent variable in equation 1. For the reasons offered in Section 3, we treat our IMR variable as a poverty-related indicator. Again, we obtain a statistically significant coefficient value for IMF (0.03), alluding to an increase of infant mortality due to IMF lending in the recipient countries of our sample. The respective results are presented in Table 2 of the Appendix 2 ( $2^{\text {nd }}$ column).

Overall, what stems from the various poverty variables analysis (the IMR included) is the persistent result of a detrimental effect of IMF lending on poverty, with indications of an even more aggravating impact on the poorest ones.

Placing the HDI variable on the left side of equation 1 we obtain the results presented in Table 2 of the Appendix 2 ( $1^{\text {st }}$ column). HDI obtains a negative and statistically significant value at the $1 \%$ level, and thus, a deterioration in terms of overall human well-being can be deduced due to the IMF lending factor for the recipient countries.

Other interesting narratives about poverty and human development in the developing countries where IMF programs have been implemented can be outlined if we turn to the rest of our explanatory variables of equation 1.

Oil production, positively affects all of the 'poverty line' variables, as well as the HDI as attested by the negative estimated values for OIL (columns 5-10 of Table 1 of the Appendix 2) and the positive one for HDI (1 $1^{\text {st }}$ column of Table 2 of the Appendix 2). Besides, it does not affect in a statistically significant manner the IMR variable $\left(2^{\text {nd }}\right.$ column of Table 2 of the Appendix 2). We can deduce that-logically enough-the existence of significant quantities of natural resources does alleviate poverty and further improves the overall well-being of the respective population, but only on the average. Only in a, say, generic manner are natural resources beneficial for the entirety of the population. Only when composite indices (e.g., HDI), or indices which rather address the totality of the economy or the population than focus on specific segments or groups are used ('poverty line' variables), is the positive character of the existence of natural resources fully revealed. When we focus on specific categories of more 'individualized' definitions of poverty ('gap' and 'headcount' variables or, even more significantly, the IMR variable), the existence of natural resources seems to be rather irrelevant.

Overall, the existence of abundant natural resources in developing countries ameliorates poverty at a national rather than at a more 'individualized' level, and increases the well- 
being of the population. Theories based on the 'Dutch disease' hypothesis, especially for 'Third World' countries, like the so-called 'political resource curse' theory, as discussed in Section 5, seem to be confirmed by these results.

When we turn to the urbanization control variable URBAN, a similar narrative emerges. Most of the poverty variables used (Table 1 of Appendix 2) are positively affected by urbanization (negative estimated coefficient values for URBAN), alluding to a reduction of poverty wherever the population tends to be concentrated in big urban centres. The highly significant, and extremely high negative estimated values of the 'headcount' and 'gap' variables, both at $\$ 1.25$ and $\$ 2$ per day (columns 1-4 of Table 1 of Appendix 2) are difficult to accept in terms of economic interpretation. The respective values for the various 'poverty line' variables, however, seem more plausible and interpretable from an economic point of view. They also seem to form a kind of a correlate with the respective behaviour of the OIL variable, as already analysed: with the exception of the GAP RUR LN variable, a clear amelioration of poverty nationwide is the main effect caused by an increased urbanization in developing countries. The estimated coefficients of the two 'urban line' variables (columns 9 and 10 of Table 1) are not statistically significant, probably due to endogeneity issues among variables that describe the same thing.

Finally, URBAN exerts a beneficial impact to both HDI and IMR, as is depicted in Table 2 of Appendix 2: it positively affects human development as is attested by the positive coefficient value URBAN obtains in relation to the HDI, while at the same it also reduces infant mortality as is attested by the respective negative value in relation to the IMR variable.

Especially with regard to the HDI, the highly positive and statistically significant coefficient value seems to be confirming the kind of an inherent 'urbanization bias' which HDI supposedly suffers from by construction as mentioned by, for example, Cashin, Mauro, Patillo \& Sahay (2001).

In sum, urbanization has a beneficial impact in terms of overall well-being, infant mortality rates, and poverty.

\section{Conclusions}

Responding to the highly polemical character of the debate of whether IMF's multiple interventions in Third World countries during the last few decades have actually been beneficial or deleterious for the overall wellbeing of the populations of the recipient countries, we have run a series of regressions of a broad set of poverty and human development variables, on an 'IMF-lending' variable, as well as on two control variables accounting for the urbanization and the natural resources factors.

Poverty is found to be negatively affected by IMF lending in a universal manner. Even poverty-related variables which encompass a broader spectrum of qualitative factors like the infant mortality rate are indisputably aggravated. This detrimental impact is reflected on overall human development, as well.

Additional explanations about the phenomenon of poverty in Third World countries with recourse to IMF lending have also been sought. We have turned an eye to the natural 
resources and urbanization factors. In relation to the former, poverty is normally ameliorated by the existence of abundant oil resources-even though in a generic manner, and at a national rather than at an 'individualized' level. The HDI, which measures the overall wellbeing of a society's population, is also improved by the existence of natural resources, whereas the IMR is not influenced in a statistically significant manner by it.

Finally, urbanization seems indeed to be adding further explanatory power to the model. It also ameliorates poverty at a national level as the existence of natural resources does, whereas it also increases the HDI and reduces the IMR.

Either the credibility of the IMF's own programmatic declarations regarding poverty amelioration or the efficacy of its 'conditionalities' as implemented so far in a broad set of Third World countries is contested by the findings of our empirical analysis.

\section{References}

Adam C. S. and Bevan D. L. (2001) 'Fiscal policy design in low-income countries', Paper prepared for the UNU/WIDER research project on 'New Fiscal Policies for Poverty Reduction and Growth', Helsinki: UNU/WIDER.

Adedeji A (1999) 'Structural adjustment policies in Africa'. International Social Science Journal, 51, 521-528.

Adeyemi S L, Ijaiya G T, Ijaiya M A and Kolawole S D (2006) 'Determinants of human development in Sub-Saharan Africa',African Journal of Economic Policy, 13, 15-33.

Akabzaa T and Darimani A (2001) 'Impact of mining sector investment in Ghana: a study of the Tarkwa mining region', Draft report for SAPRI.

Akinbobola T O and Saibu M O (2004) 'Income inequality, unemployment, and poverty in Nigeria: a vector autoregressive approach',The Journal of Policy Reform, 7, 175-183.

Alexander S S (1952) 'Effects of a Devaluation on a Trade Balance',Staff Papers International Monetary Fund, 2, 263-278.

Ames B, Brown W, Devarajan S and Izquierdo A (2001), 'Macroeconomic policy and poverty reduction', International Monetary Fund Draft for Comments, Washington, D.C.: IMF.

Anwar T (1996) 'Structural Adjustment and Poverty: the case of Pakistan',The Pakistan Development Review, 35, 911-926.

Appleton S, Kagugube J and Muwonge J (1999) 'Changes in poverty in Uganda, 1992-1997', University of Oxford,Working Paper Series no. 22.

Banchirigah S M (2006) 'How have reforms fuelled the expansion of artisanal mining? Evidence from sub-Saharan Africa', Resources Policy, 31, 165-171.

Bayliss K (2002) 'Privatisation and poverty The distributional impact of utility privatisation', University of Greenwich, Working Paper Series no. 16.

Berg A and Krueger A (2003) 'Trade Growth and Poverty', IMF, Working Paper Series no. 30.

Bernal R L (1984) 'The IMF and class struggle in Jamaica, 1977-1980',Latin American Perspectives, 11, 53-82.

Bird G (2004) 'Growth, poverty and the IMF'. Journal of International Development, 16, 621636.

Boyer R (2012) 'The four fallacies of contemporary austerity policies: the lost Keynesian legacy'. Cambridge journal of economics, 36, 283-312. 
Bradshaw W Noonan, GashR L and Buchmann Sershen C (1993) 'Borrowing against the future: children and Third World indebtedness'. Social Forces, 71, 629-656.

Cashin P, Mauro P, Patillo C. and Sahay R (2001) 'Macroeconomic policies and poverty reduction: stylized facts and an overview of research', IMF,Working Papers Series no. 135.

Chossudovsky M (2003)The Globalization of Poverty and the New World Order, Pincourt (Quebec): Global Research, Center for Research on Globalization (CRG).

Collier P and Gunning J W (1999) 'The IMF's Role in Structural Adjustment' The Economic Journal, 109, F634-F651.

Corden M and Neary P J (1982) 'Booming sector and de-industrialisation in a small open economy', The Economic Journal 92, 825-848.

Council of Economic Advisers (1973) Annual Report of the Council of Economic Advisers, Washington D.C.: United States Government Printing Office.

Crisp B F and Kelly M J (1999) 'The socioeconomic impact of structural adjustment',International Studies Quarterly, 43, 533-552.

Dabour N M (1999) 'The impact of stabilization and Structural Adjustment Programmes (SSAPs) on human development and poverty alleviation. The experience of some OIC member countries',Journal of Economic Cooperation, 20, 39-66.

De Vogli R and Birbeck G L (2005) 'Potential impact of adjustment policies on vulnerability of women and children to HIV/AIDS in Sub-Saharan Africa', Journal of Health Population and Nutrition, 23, 105-120.

Dell S (1982) 'Stabilization: The Political Economy of overkill', World Development, 10, 597 612.

Dercon S and Krishnan P (1998) 'Changes in poverty in rural Ethiopia 1989-1995: Measurement, robustness tests and decomposition', Department Economie- Center for Economic Studies Discussion Paper Series DPS 98.19, Leuven Katholikie Universiteit.

Díaz-Alejandro C F (1963) 'A Note on the Impact of Devaluation and the Redistributive Effect', The Journal of Political Economy, 71, 577-580.

Díaz-Alejandro C F (1984) 'Latin-American debt: I don't think we are in Kansas anymore',Brookings Papers on Economic Activity, 2, 335-389.

Diz A C (1984)'The Conditions Attached to Adjustment Financing; Evolution of the IMF Practice', The International Monetary System: Forty Years After Bretton WoodsProceedings, 2140-325.

Dollar D and Kraay A (2002) 'Growth is good for the poor',Journal of Economic Growth, 7, 195-225.

Dornbusch R (1973) 'Devaluation, money, and nontraded goods', The American Economic Review, 63, 871-880.

Downing T E (2002)'Avoiding new poverty: mining-induced displacement and resettlement', London: The International Institute for Environment and Development - The Mining, Minerals and Sustainable Development (MMSD) project.

Elbadawi I A, Ghura D and Uwujaren G (1992) 'World Bank adjustment lending and economic performance in Sub-Saharan Africa in the 1980s. A comparison with other low-income countries', World Bank, Working Paper Series no. 1000.

Foxley A (1983)Latin American Experiments in Neoconservative Economics, Berkeley and LosAngeles: University of California Press. 
Frey R S and Field C (2000) 'The determinants of infant mortality in the Less Developed Countries: a cross-national test of five theories',Social Indicators Research, 52, 215-234.

Friedman M (1969)The optimum quantity of money: And other essays, Chicago: Aldine Transaction.

Friedman M and Heller W W (1969)Monetary vs. fiscal policy, New York: W. W. Norton and Company, Inc.

Friedman M (1975) Letter to General Pinochet on Our Return from Chile and His Reply, Available: $\quad$ http://wwww.naomiklein.org/files/resources/pdfs/friedman-pinochetletters.pdf.

Friedman M (1982) 'Monetary Policy: Theory and Practice',Journal of Money, Credit and Banking, 14,98-118.

Friedman M (1983) 'Monetarism in Rhetoric and in Practice',Bank of Japan Monetary and Economic Studies, 1, 1-14.

Geo-Jaja M A and Mangum G (2001) 'Structural adjustment as an inadvertent enemy of human development in Africa',Journal of Black Studies,32, 30-49.

Girvan N (1980) 'Swallowing the IMF medicine in the seventies',Development Dialogue, 2, 55-74.

Grant J P (1984)The State of the World's Children, Oxford: Oxford University Press, 1984.

Gudikunst N (2004) 'The Social Impact of the International Monetary Fund: Structural Adjustment Programs in Latin America from 1980-2000', Master's Dissertation (Graduate School of Creighton University, Omaha, Nebraska).

Gujarati D (2011)Econometrics by example, Hampshire, New York: Palgrave Macmillan.

Gylfason T (2001) 'Lessons from the Dutch disease: causes, treatment, and cures', Institute of Economic Studies, Working Papers 1987-2001 (Formerly Iceland Economic Paper Series no. W01:6).

Haddad L, Ruel M T and Garrett J L (1999) 'Are urban poverty and undernutrition growing? Some newly assembled evidence', Food, Consumption and Nutrition Division Discussion Paper No. 63, International Food Policy Research Institute.

Hajro Z and Joyce P J (2009) 'A true test: do IMF programs hurt the poor?' Applied Economics,41, 295-306.

Handa S and King D (1996) 'Structural adjustment policies, income distribution and poverty: A review of the Jamaican experience', World Development,25, 915-930.

Helleiner G K, Cornia G A and Jolly R (1991) 'IMF adjustment policies and approaches and the needs of children', World Development, 19, 1823-1834.

Hilson G and Potter C (2005) 'Structural adjustment and subsistence industry: artisanal gold mining in Ghana',Development and Change, 36, 103-131.

Hojman D E (1996) 'Economic and other determinants of infant and child mortality in small developing countries: the case of Central America and the Caribbean',Applied Economics, 28, 281-290.

Huang J (1995) 'Structural disarticulation and Third World human development', International Journal of Comparative Sociology, 36, 164-183.

IMF (2011) Articles of Agreement of the International Monetary Fund (1944), Washington DC: International Monetary Fund.

Ismi A (2004)Impoverishing a continent: the World Bank and the IMF in Africa, The Halifax Initiative Coalition. Ottawa: Canadian Centre for Policy Alternatives-National Office. 
Jamal H (2003) 'Poverty and inequality during the adjustment decade: Empirical findings from household surveys', The Pakistan Development Review, 42, 125-135.

Jensen N and Wantchekon L (2004) 'Resource wealth and political regimes in Africa',Comparative Political Studies, 37, 816-841.

Johnson H G (1972) 'The monetary approach to Balance-of-Payments theory',The Journal of Financial and Quantitative Analysis - Supplement: Outlook for the Securities Industry, 7, 1555-1572.

Johnson O and Salop J (1980)'Distributional aspects of stabilization programs in developing countries', IMF Staff Papers No. 27.

Jolly R (1991) 'Adjustment with a human face: a UNICEF record and perspective on the 1980s',World Development, 19, 1807-1821.

Kaldor N (1970) 'The new monetarism',Lloyds Bank Review, 97, 1-18.

Kanbur R S (1987) 'Measurement and Alleviation of Poverty: With an Application to the Effects of Macroeconomic Adjustment', IMF Staff Papers No. 34.

Kanji N (1995) 'Gender, poverty and economic adjustment in Harare, Zimbabwe',Environment and Urbanization, 7, 37-56.

Killick T and Malik M (1992) 'Country experiences with IMF programmes in the 1980s', The World Economy, 5, 599-632.

Konadu-Agyemang K (2000) 'The best of times and the worst of times: structural adjustment programs and uneven development in Africa: the case of Ghana',Professional Geographer, 52, 469-483.

Krugman P and Taylor L (1978) 'Contractionary effects of devaluation',Journal of International Economics, 8, 445-456.

Kyle, S. (1989). 'Structural Adjustment, Agriculture, and Natural Resources in Africa', in J. P. Lassoie and S. C. Kyle (ed.), Policy Reform and Natural Resource Management in SubSaharan Africa, Ithaca NY: College of Agriculture and Life Sciences Cornell University, 11-33.

Laffer A B and Agmon T (1978) 'Trade, payments and adjustment: the case of the oil price rise',Kyklos, 31, 68-85.

Lohani S (2004) 'Effect of foreign aid on development: does more money bring more development?' The Park Place Economist, 12, 110-120.

Loko B, Mlachila M, Nallari R and Kalonji K (2003) 'The impact of external indebtedness on poverty in low-income countries', IMF, Working Paper Series no. 61.

Lopes C (1999) 'Are structural adjustment programmes an adequate response to globalisation?', International Social Science Journal, 162, 511-519.

Lugalla J L (1995) 'The impact of structural adjustment policies on women's and children's health in Tanzania', Review of African Political Economy, 22, 43-53.

Mazur R E (2004) 'Realization or deprivation of the right to development under globalization? Debt, structural adjustment, and poverty reduction programs',GeoJournal, 60, 61-71.

Meade J (1956) 'The price mechanism and the australian balance of payments',Economic Record, 32, 239-256.

Meade J (1957) 'The Balance-of-Payments problems of a European free-trade area',The Economic Journal, 67, 379-396.

Meertens B (2000) 'Agricultural performance in Tanzania under structural adjustment programs: is it really so positive?',Agriculture and Human Values, 17, 333-346. 
Meller P (1991) 'Adjusting and social costs in Chile during the 1980s',World Development, 19, $1545-1561$.

Minujin A (1995) 'Squeezed: the middleclass in Latin America',Environment and urbanization, 7, 153-165.

Morrison K M (2007) 'Natural resources, aid, and democratization: A best-case scenario',Public Choice, 131, 365-386.

Mosley P, Subasat T. and Weeks J (1995) 'Assessing adjustment in Africa',World Development, 23, 1459-1473.

Mussa M and Savastano M (2000) The IMF approach to economic stabilization, in NBER Macroeconomics Annual(1999), 14, Available: http://papers.nber.org/books/bern00-1.

Noorbakhsh F and Noorbakhsh S (2006) 'The Effects of Compliance with Structural Adjustment Programmes on Human Development in Sub-Saharan Africa', in A. Paloni and M. Zanardi (ed.), The IMF, the World Bank and Policy Reforms, London: Routledge, 147-161.

Oberdabernig D A (2012) 'Revisiting the Effects of IMF Programs on Poverty and Inequality', WU Vienna University of Economics and Business, Working Paper Series no. 144.

OECD (2001) Glossary of Statistical Terms, Available: http://stats.oecd.org/glossary/detail.asp?ID=1347.

Palley T (2009) The fiscal austerity trap, Available: http://www.newamerica.net/files/Thomas_Palley-The_Fiscal_Austerity_Trap. pdf, Erişim Tarihi, 25, 2010.

Pastor M J (1987) 'The effects of IMF programs in the Third World: Debate and evidence from Latin America', World Development, 15, 249-262.

Perotti R (2012) 'The "Austerity Myth": Gain Without Pain?', in Fiscal Policy after the Financial Crisis, Chicago: University of Chicago Press.

Petras J and Brill H (1986) 'The IMF, austerity and the state in Latin America',Third World Quarterly, 8, 425-448.

PolakJ J (1990) 'Financial policies and development', International Center for Economic Growth, Occasional Paper Series no. 11.

Polak J J (1991) 'The changing nature of IMF conditionality', OECD Development Centre, Working Paper no. 41.

Polak J J (1997) 'The IMF monetary model. A hardy perennial',Finance and Development, 34, 16-19.

Ravallion M (2001) 'On the urbanization of poverty',World Bank, Policy Research Working Paper no. 2586.

Rodrik D (1996) 'Understanding economic policy reform',Journal of Economic Literature, 34, 9-41.

SAPRIN, S. A. (2001)The policy roots of economic crisis and poverty. A multi-country participatory assessment of structural adjustment, Executive Summary, Washington, D.C.: Joint World Bank/Civil Society Structural Adjustment Participatory Review Initiative (SAPRI) and the Citizens' Assessment of Structural Adjustment (CASA).

Sen A (1995)Mortality as an indicator of economic success and failure, Innocenti Lectures, Florence: United Nations Children's Fund - International Child Development Centre.

Shandra J M, Nobles J, London B and Williamson J B (2003) 'Dependency, democracy, and infant mortality: a quantitative, cross-national analysis of Less Developed Countries', 


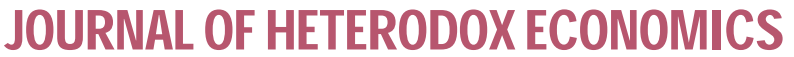

California Center for Population Research,On-Line Working Papers Series no.27.

Shen C and Williamson J B (2001) 'Accounting for cross-national differences in infant mortality decline (1965-1991) among Less Developed Countries: effects on women's status, economic dependency, and state strength',Social Indicators Research, 53, 257 288.

Simons H C (1936) 'Rules versus Authorities in Monetary Policy',Journal of Political Economy, 44, 1-30.

The Chronic Poverty Research Centre - CPRC (2005)The Chronic Poverty Report 2004-05, Manchester: University of Manchester - Institute for Development Policy and Management.

Thiele R (2003) 'The social impact of adjustment in Bolivia',Journal of International Development, 15, 299-319.

UN (2011) Human Development Report 2011. Sustainability and equity: a better future for all, United Nations Development Programme (UNDP), New York: Palgrave Macmillan.

UN (2012) World Urbanization Prospects: The 2011 Revision, United Nations - Department of Economic and Social Affairs, Population Division.

Wade R H and Sigurgeirsdottir S (2012) 'Iceland's rise, fall, stabilisation and beyond',Cambridge journal of economics, 36, 127-144.

Walton J and Ragin C (1990) 'Global and national sources of political protest: Third World responses to the debt crisis',American Sociological Review, 55, 876-890.

Wanniski J (1975) 'The Mundell-Laffer Hypothesis. A New View of the World Economy',The Public Interest, 39, 31-52.

Weissman S R (1990) 'Structural adjustment in Africa: insights from the experiences of Ghana and Senegal', World Development,18, 1621-1634.

Wiesner E (1985) 'Latin American debt: lessons and pending issues', The American Economic Review, 75, 191-195.

Whitman Marina V N, Branson W H, Fand D I, Krause L B and Salant W S (1975) 'Global Monetarism and the Monetary Approach to the Balance of Payments',Brookings Papers on Economic Activity, 3, 491-555.

Williamson J (1990) What Washington means by policy reform, in Latin American Adjustment: How Much Has Happened?(2), Available: https://edisk.fandm.edu/min/IST-325Ecuador/What-Washington-Means-by-Policy-Reform.pdf. 


\section{Appendix 1}

Table 1 - Variables used and data sources

\begin{tabular}{|c|c|c|c|c|c|}
\hline \multicolumn{3}{|c|}{ Dependent Variable } & \multicolumn{3}{|c|}{ Independent Variable } \\
\hline Variable & Source & Measured in & Variable & Source & $\begin{array}{l}\text { Measured } \\
\text { in }\end{array}$ \\
\hline $\begin{array}{l}\text { Poverty } \\
\text { Gap } \\
\text { variables }\end{array}$ & $\begin{array}{l}\text { WDI } \\
2013\end{array}$ & $\begin{array}{l}\text { Percentages from the } \\
\text { poverty line }\end{array}$ & $\begin{array}{l}\text { IMF } \\
\text { lending }\end{array}$ & $\begin{array}{l}\text { World Bank } \\
\text { Data Bases }\end{array}$ & $\begin{array}{l}\text { Current } \$ \\
\text { prices }\end{array}$ \\
\hline $\begin{array}{l}\text { Poverty } \\
\text { Headcount } \\
\text { variables }\end{array}$ & $\begin{array}{l}\text { WDI } \\
2013\end{array}$ & $\begin{array}{l}\text { Percentages of } \\
\text { population living } \\
\text { below the respective } \\
\text { poverty line }\end{array}$ & $\begin{array}{l}\text { Oil } \\
\text { production }\end{array}$ & $\begin{array}{c}\text { US Energy } \\
\text { Information } \\
\text { Administration }\end{array}$ & $\begin{array}{l}\text { Thousands } \\
\text { of barrels } \\
\text { per day }\end{array}$ \\
\hline $\begin{array}{l}\text { Infant } \\
\text { Mortality } \\
\text { Rate } \\
\text { (IMR) }\end{array}$ & $\begin{array}{l}\text { WDI } \\
2013\end{array}$ & $\begin{array}{l}\text { Number of deaths } \\
\text { under one year of } \\
\text { age occurring among } \\
\text { the live births in a } \\
\text { given geographical } \\
\text { area during a given } \\
\text { year, per } 1,000 \text { live } \\
\text { births }\end{array}$ & $\begin{array}{l}\text { Urbanizatio } \\
n\end{array}$ & WDI 2013 & $\begin{array}{l}\text { Percentage } \\
\text { of the urban } \\
\text { to total } \\
\text { population } \\
\text { of a country }\end{array}$ \\
\hline $\begin{array}{l}\text { Human } \\
\text { Developm } \\
\text { ent Index } \\
\text { (HDI) }\end{array}$ & $\begin{array}{c}\text { United } \\
\text { Nations - } \\
\text { 'HDI } \\
\text { trends } \\
1980- \\
2010 ' \\
\text { report }\end{array}$ & $\begin{array}{l}\text { A scale of values } \\
{[0,1]}\end{array}$ & & & \\
\hline
\end{tabular}

Note: WDI stands for World Bank's World Development Indicators database, downloaded from the World Bank. 
Appendix 1

Table 2 - Sample of countries

\begin{tabular}{|l|l|l|l|l|}
\hline Afghanistan & China & Haiti & Mexico & Sri Lanka \\
\hline Albania & $\begin{array}{l}\text { Congo, Democratic } \\
\text { Republic of }\end{array}$ & Honduras & Moldova & Sudan \\
\hline Algeria & Congo, Republic of & India & Mongolia & Tajikistan \\
\hline Argentina & Costa Rica & Indonesia & Morocco & Tanzania \\
\hline Armenia & Cote d' Ivore & Jamaica & Mozambique & Thailand \\
\hline Azerbaijan & Dominica & Jordan & Nepal & Togo \\
\hline Bangladesh & Dominican Republic & Kazakhstan & Nicaragua & Tunisia \\
\hline Belarus & Ecuador & Kenya & Niger & Turkey \\
\hline Benin & Egypt & Kyrgyz Republic & Pakistan & Uganda \\
\hline Bolivia & El Salvador & Laos & Panama & Ukraine \\
\hline Bosnia-Herzegovina & Ethiopia & Latvia Republic & Papua New Guinea & Uruguay \\
\hline Brazil & Fiji & Lebanon & Peru & Uzbekistan \\
\hline Bulgaria & Gabon & Lesotho & Philippines & Venezuela \\
\hline Burkina Faso & Gambia & Liberia & Romania & Vietnam \\
\hline Burundi & Georgia & Lithuania & Russian Federation & Yemen \\
\hline Cameroon & Ghana & FYROM & Rwanda & Zambia \\
\hline Cape Verde & Grenada & Madagascar & Senegal & Zimbabwe \\
\hline $\begin{array}{l}\text { Central African } \\
\text { Republic }\end{array}$ & Guatemala & Malawi & Serbia & \\
\hline Chad & Guinea & Mali & Sierra Leone & \\
\hline Chile & Guyana & Sauritania & & \\
\hline
\end{tabular}




\section{Appendix 2 - Regressions Results}

Table 1 - Poverty ('gap' and 'headcount') Variables

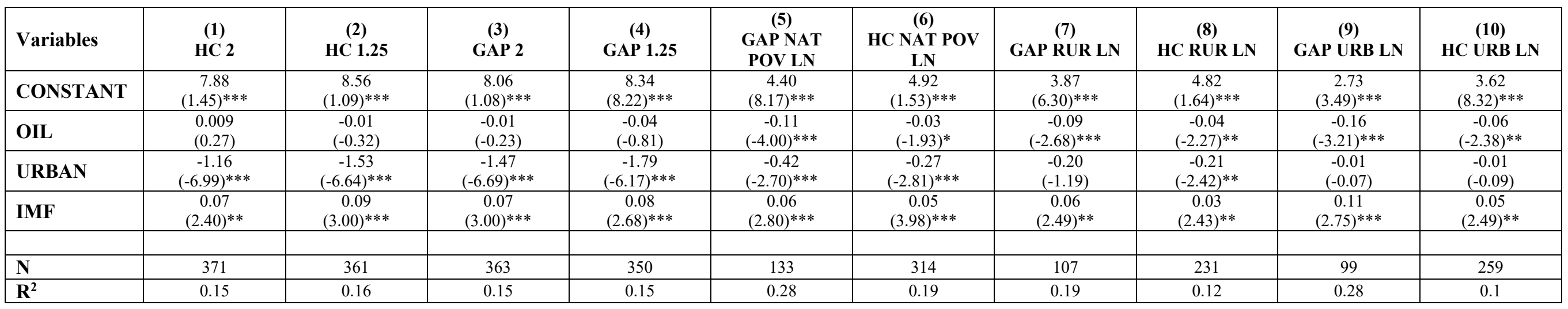

Notes:

1. GAP = Poverty 'Gap' variables at various poverty lines

$\mathrm{HC}=$ Poverty 'headcount' variables at various poverty lines

NAT.POV.LN= 'National poverty line' variables

URB.POV.LN= 'Urban poverty line' variables

RUR.POV.LN= 'Rural poverty line' variables

2. '***', '**', and '*' mean statistically significant at the $1 \%, 5 \%$, and $10 \%$ level, respectively 
Appendix 2

Table 2 - HDI and IMR variables

\begin{tabular}{|l|c|c|}
\hline Variables & $\mathbf{( 1 )}$ & $\mathbf{( 2 )}$ \\
& HDI & 6.86 \\
\multirow{2}{*}{ CONSTANT } & -2.46 & $(3.59)^{* * *}$ \\
\hline \multirow{2}{*}{ OIL } & $(-1.23)$ & -0.004 \\
& 0.007 & $(-0.80)$ \\
\hline \multirow{2}{*}{ URBAN } & $(2.50)^{* *}$ & -0.78 \\
& 0.45 & $(-1.54)^{* * *}$ \\
\hline \multirow{2}{*}{ IMF } & $(8.67)^{* * *}$ & 0.03 \\
& -0.008 & $(9.34)^{* * *}$ \\
\hline & $(-7.48)^{* * *}$ & 1597 \\
\hline $\mathrm{N}$ & & 0.31 \\
\hline
\end{tabular}

Note: '***', '**', and '*' mean statistically significant at the $1 \%, 5 \%$, and $10 \%$ level, respectively. 